УДК: 94(477.83/.86)“189/191”

\section{Микола ГУЙВАНЮК}

Чернівецький національний університет імені Юрія Федьковича, Чернівці (Україна)

\author{
Mykola GUIVANIUK \\ Yuriy Fed'kovych Chernivtsi National \\ University, Chernivtsi (Ukraine) \\ buk6@ukr.net
}

\section{ВПЛИВ ЛІТЕРАТУРНОЇ ІНТЕЛІГЕНЦЇ̈ НА СТРАЙКОВИЙ РУХ СІЛЬСЬКОГОСПОДАРСЬКИХ РОБІТНИКІВ ГАЛИЧИНИ Й БУКОВИНИ ПОЧАТКУ ХХ ст.}

\author{
LITERARY INTELLECTUALS' \\ IMPACT ON FARM LABORERS' STRIKE \\ MOVEMENT IN GALICIA AND BUKOVYNA \\ IN EARLY TWENTIETH CENTURY
}

Ключевые слова: агитация, крестьянские забастовки, Галичина, Буковина, украинские писатели.
Гуйванюк Николай. Влияние литературной интеллигенции на забастовочное движение сельскохозяйственных рабочих Галичины и Буковины начала XX в.

В статье раскрыто одно из событий отечественной истории начала XX в. - массовые забастовки украинского крестьянства Галичины и Буковины как средство отстаивания своих экономических прав. Показана ведущая роль в организации этих забастовок представителей светской интеллигенции, в частности активной ее части - писателей и публицистов. Отмечено значительный вклад организации забастовочного движения И. Франко, М. Павлика, В. Будзиновського, С. Даниловича, Леся Мартовича, А. Чайковского и К. Трилевского.

\begin{abstract}
Постановка проблеми. Однією із знакових подій початку XX ст. стали масові страйки українського селянства Галичини й Буковини - як засіб відстоювання своїх економічних прав, що стало свідченням піднесення національної та суспільної активності українців та подальшого поступу українського національного руху загалом. Провідну роль у цих процесах відіграла нова генерація світської інтелігенції, зокрема найактивніша ії частина - письменники та публіцисти.

Науковий інтерес до порушеної проблеми обгрунтований також необхідністю адекватно відобразити історичний період зароджені і перебігу страйкового руху галицького й буковинського селянства, що дасть можливість краще осмислити суть і спрямованість змін, які відбуваються нині у державі.
\end{abstract}

Аналіз останніх досліджень і публікацій. Означена тема частково порушувалася в окремих дослідженнях В.Ботушансько ${ }^{1}$, М.Вітенка ${ }^{2}$, Ф.Погребенника ${ }^{3}$ та О.Красівського ${ }^{4}$. Проте зазначені автори розглядали участь галицьких і буковинських письменників у рільничих страйках початку XX ст. вибірково. Тому комплексного дослідження із зазначеної проблематики ще й досі немає.

Мета статті полягає в тому, щоб розкрити вплив літературної інтелігенції на страйковий рух сільськогосподарських робітників Галичини й Буковини початку XX ст.

Для досягнення мети автор ставить наступні завдання:

проаналізувати передумови та причини аграрних страйків;

визначити просвітницьку та агітаційну роль літературної інтелігенції в організації страйкового pyxy;

дослідити масштаби практичної допомоги письменників у безпосередній організації страйків;

розкрити участь окремих літераторів-правників у захисті страйкуючих у судах;

показати відображення страйкового руху у художній творчості галицьких i буковинських письменників.

Виклад основного матеріалу дослідження. Незважаючи на широкі можливості, надані австрійською конституцією 1897 р. народам, що населяли імперію, у сфері політичного, суспільного та соціально-економічного розвитку, у силу певних об'єктивних обставин, галицькі та буковинські українці не змогли повною мірою ними скористатися. Насамперед це стосувалося економічного поступу. Головна причина полягала у недовершеності аграрної реформи 1848 р. у цих окраїнних землях імперії. Скасування панщини не привело до ліквідації великого землеволодіння. В результаті, незважаючи на те, що шляхта перестала існувати як самостійна верства, вона i надалі зберігала своє привілейоване становище. Станом на 1892 р. великим землевласникам Східної Галичини належало від 32 до 43 \% усієї орної землі (найпоширенішими були латифундії) від 500 га, а на селянську (малу) земельну власність припадало $57 \%$ земель 5 . На Буковині нараховувалося 56 володінь розміром понад 100 га, що становило понад $49 \%$ усього великого землеволодіння ${ }^{6}$. В той же час 3 великої земельної власності користало близько 59 тис. осіб, на малій жило 2,3 млн осіб, а 2,7 млн осіб були взагалі безземельними, або мали таку незначну кількість, що це не давало їм достатніх засобів до життя ${ }^{7}$. Такі обезземелені селяни змушені були йти в найми і творили сільський пролетаріат.

Слушним $є$ зауваження В. Ботушанського ${ }^{8}$, що дані про землеволодіння не завжди $є$ точним відбитком землекористування. Адже більшість великих землеволодінь надавалися власниками в оренду і суборенду місцевим підприємливим полякам, євреям та вірменам, які не завжди дбали про інтенсифікацію 
ввіреного їм господарства, а намагалися отримувати прибутки за рахунок посилення експлуатації та заниження платні найманим робітникам - українським селянам. Звичайно, що такі дії орендарів наштовхувались на певний супротив - стихійні бунти, псування реманенту, підпали тощо. Ці форми непокори на основі реальних фактів описав В. Стефаник у новелі "Палій"9. Однак такі форми невдоволення так і не переросли в потужні акції, які б принесли певні результати. Головна причина цього полягала у тому, що, 3 одного боку, не було серйозних спроб організації масового спротиву, а 3 другого, внаслідок багаторічного перебування в конституційно-правовому полі монархії Габсбургів, а також культурно-просвітньої роботи українських національних товариств і церкви у галицького й буковинського селянства була достатньо висока громадянська і правова свідомість.

Одним із наслідків емансипаційних процесів у Європі другої половини XIX ст. стала боротьба індивіда за особисті політичні, соціальні та економічні права. Особливо активізувалися у 80 - 90$\mathrm{x}$ роках XX ст. робітники у європейських країнах Бельгії, Франції, Англії, Швейцарії. Вони піднімалися на протестні акції - мітинги, демонстрації, страйки, бойкоти тощо. Незважаючи на складність такої боротьби, позитивних результатів було досягнуто. Зокрема, вдалося, певною мірою, врегулювати деякі аспекти соціально-трудових відносин, насамперед тих, що стосувалися заробітної платні, тривалості робочого дня та умов праці. Невдовзі застрайкували робітники Праги, Відня, Кракова, Львова та інших міст. Оскільки у зазначений період українська преса набула достатнього розвитку i мала значну читацьку аудиторію, то українська спільнота постійно інформувалася про згадані протестні акції ${ }^{10}$.

Починаючи 31890 p., у Львові, а згодом і в Чернівцях, Дрогобичі, Станіславові та інших містах стали традиційними першотравневі демонстрації, під час яких робітники висували економічні вимоги до роботодавців. Ці акції підтримали і окремі українські літератори, зокрема, М. Павлик у статті "Робітниче свято Першого мая" не тільки виклав історію відзначення вказаної дати в Європі, але і закликав долучитися до цього українське селянство: “[ $[.$. святкуйте сей раз Перше Мая і меж собою, братя хлібороби, сходіться того дня, радьтеся над своєю долею"11.

Iз утворенням у 1890 p. Русько-української радикальної партії - першої політичної партії європейського зразка, програма якої передбачала відстоювання політичних, економічних та соціальних інтересів українських селян Галичини й Буковини, iii активні діячі 3 числа літературної інтелігенції I. Франко, М. Павлик, В. Будзиновський та ін. висунули ідею організації страйків сільськогосподарських робітників 3 метою підвищення заробітної платні. Одним 3 найактивніших пропагандистів та організаторів селянського страйку став відомий на той час публіцист В. Будзиновський. На VI з’їзді Радикальної партії 13.09.1897 р. ним бу- ло виголошено реферат "Страйки по громадах", у якому переконливо доводилося, що: “Одиноким средством а цілком певним є страйк і бойкот. При помочі страйку можем добитися своїх прав. Страйками можна примусити панів, щоби згодилися на наші вимоги. Якщо не згодяться на реформу виборчу, ми застрайкуємо..."12. Зазначена пропозиція здобула підтримку I. Франка, М. Павлика, С. Даниловича, К. Трильовського та інших літераторів - учасників з'їзду. Про це свідчила резолюція з'їду викладена у виступі В. Охримовича: “'З’ізд узнає, що страйк і бойкот, се одиноке глобальне оружиє, котрим руский народ зможе 3 себе скинути ярмо економічної i політичної неволі. Для того взиває головний заряд партії $[. .$.$] розпочати як найсильнішу акцію зі страй-$ ком, щоби по змозі уряджувалося як в ділах економічних, так i в політичних. Організувати якнайбільше страйків і бойкотів, котрі будуть школою для переведення загального аграрного страйку"13. 3 того часу розпочалася агітаційнопросвітницька робота серед селянства 3 організації такого страйку, головна роль у методичноінформаційному забезпеченні якої належала представникам літературної інтелігенції.

Після розколу РУРП у 1899 р. частина літераторів увійшла до складу Української національно-демократичної парті. В подальшому діячі обидвох партій відіграли значну роль в організації селянських страйків у Галичині й Буковині.

У 1901 р. провід Української національнодемократичної партії (УНДП) доручив В. Будзиновському редагувати друкований орган партії - газету “Свобода”. Маже в кожному номері він агітував українське селянство до загального страйку, в результаті чого той здобув неабияку популярність серед селян.

На конгресі УНДП у 1901 р. В. Будзиновський запропонував підготувати та організувати найближчим часом страйк селян Східної Галичини. Цю ідею підтримали представники проводу українського національного руху. Письменники та публіцисти, використовуючи будь-яку легальну можливість, взялися за підготовку страйку, насамперед роз'яснюючи селянам через пресу, а також особисто - на зборах читалень, народних вічах - правила організації успішного страйку у межах чинного законодавства. Зокрема, під час віча у Коломиї, яке відбулося 18.04.1902 р., “[...] головним питанням, що розглядалося на ньому було “економічне положення нашого селянства, i як його піднести”. Реферував К. Трильовський... бесідник подав приміри, як платять робітникам в Коломийськім повіті... молотільник в середньому заробляє 18 20 крейцерів... Віче закликало кожну громаду закладати в себе комітети заробкові кількістю не менше 5 чоловік..."14. М. Павлик переконував: "Мужики не перестають емігрувати, а пани бавитись, програвати по касинах здертих з мужиків мільйонів. А чи мусить так бути? Ні! ...Оружиєм є страйк та бойкот"15. Питання підготовки селянського страйку також порушував М. Павлик у листі до з'їзду Русько-української радикальної партії ${ }^{16}$. Слушною, на наш погляд, була 
його пропозиція уміло використати наслідки страйків для подальшого розвитку українського національного руху.

До організації аграрного страйку особливо спричинився талановитий публіцист та редактор В. Будзиновський, який мав природний дар дохідливо пояснювати народу важкодоступну інформацію. Це насамперед стосується його відомих статей "Про страйк і бойкот"17, “Про страйки" льно описав, як організувати у громаді страйк. Їх частково або повністю публікували майже всі українські часописи. В. Будзиновський доступно роз'яснив селянам як організувати страйк і бойкот, не порушивши норми австрійського законодавства. В. Будзиновський рекомендував перед страйком провести роз'яснювальну роботу серед жителів сусідніх населених пунктів, щоб вони “тримали” солідарність i не погоджувалися працювати у роботодавця, якому оголошено бойкот. Адже “[...] як хлопи виграють справу в однім селі, як оден пан буде більше платити за роботу, то й інші пани в сусідніх селах змушені будуть підвищити платню"19.

Велика підготовча робота, що іiї здійснили представники українського національного проводу, серед яких відзначилися окремі письменники, привела до того, що влітку 1902 р. розпочався найбільший у Східній Європі масовий страйк селян, який охопив понад 100 тисяч женців у 500-ах населених пунктах Східної Галичини та Північної Буковини. Страйкарі вимагали підвищення заробітної плати, скорочення трудового дня, забезпечення роботи взимку, скасування штрафів тощо. Значна частина їх вимог була виконана. "“...]там де платили ранійше 20 - 30 крейцерів там після страйку стали платити $60-80$ крейцарів, де платили 50, там стали платити 80 крейцарів і більше" 20 , - стверджував В. Будзиновський.

Якщо літератори - представники радикальної й народовської течій К. Левицький, Ю. Романчук, I. Франко, М. Павлик та ін. закликали всю українську інтелігенцію допомагати селянам порадами та практичними справами, то представники русофільської течії піддавали критиці такі організовані дії українського селянства. Зокрема, письменник та редактор О. Мончаловський переконував, що страйки і заворушення $\epsilon$ “[...]шкодою для самих селян тому, що підірвуть їх матеріальний стан" 21 , хоча справжньою причиною подібних заяв був страх перед реальною спробою успішної організації селянства їхніми політичними опонентами.

Як варто було очікувати, аграрні стайки призвели до “полювання на відьом”, тобто здійснювалися спроби покарати найактивніших організаторів та лідерів страйкуючих з метою залякати селянство від подібних виступів у майбутньому. Для цього залучалися правники - здебільшого поляки, які, вміло маніпулюючи законодавством та маючи підтримку крайової влади, добивалися порушення кримінальних справ стосовно страйкарів.

Правники - представники літературної інтелігенції швидко та організовано надавали необхідну правову підтримку українським селянам. Ними також було організовано інформаційну кампанію у пресі, а також у австрійському парламенті та крайових сеймах Галичини і Буковини. Серед них назвемо такі, як: Я. Весоловський, Т. Галіп, С. Данилович, M. Лагодинський, В. Левицький, О. Назарук, C. Олесницький, В. Старосольський, К. Трильовський, А. Чайковський, В. Охримович та iн.

Особливо хочеться наголосити на безкорисливій титанічній праці із захисту селян-страйкарів письменником і адвокатом А. Чайковським, тереном діяльності якого було Тернопілля. Як досвідчений правник, він аргументовано роз'яснював державним урядовцям повітового рівня міжливі покарання, які на них чекають, за порушення законодавства і переслідування українського селянства; в результаті вдалося уникнути відкриття значної кількості кримінальних справ. У той же час, А. Чайковський активно захищав українських селян у судах. Зокрема, 6-7 вересня 1902 р. в окружному суді у с. Бережанах у кримінальній справі проти 19 селян 3 с. Плотичі та с. Городля та 14 вересня того ж року проти 9 селян 3 с. Бурканова і с. Болотник - "[...] обжалуваних боронив безінтресово,"22.

Депутати австрійського парламенту Ю. Романчук та К. Левицький також намагалися використати трибуну найвищого законодавчого органу держави для захисту переслідуваних страйкарів. 21 жовтня 1902 р. вони внесли депутатський запит ${ }^{23}$, який викликав бурхливі дискусії, в результаті яких глава уряду д-р Кербер, був змушений визнати, що рільничі страйки у Галичині й Буковині мали підгрунтя.

Навіть після закінчення страйку, представники української літературної інтелігенції намагалися не залишатися осторонь цих подій. Вони аналізували причини успіхів та невдач страйкарів та намагалися дати селянам слушні практичні поради щодо відстоювання своїх економічних прав у майбутньому. Показовою у цьому плані $є$ стаття К. Трильовського, вміщена у редагованій ним "Хлопській правді” (Коломия), у якій автор звернувся до жителів Покуття і Гуцульщини влітку 1903 р. згуртуватися і знову застрайкувати. На думку автора статті: [...] нам найбільше треба жадати, щоби нам платили пішим робітникам від 1 зр 20 до 1 зр 50, а кіньми від 5 зр до 6 зр",24.

Відомий громадський діяч - письменник і публіцист М. Павлик підсумував наслідки аграрного страйку 1902 р. та виклав власну візію майбутньої боротьби українського селянства за економічні права у листі до з'їзду Русько-української радикальної партії $^{25}$, що відбувся 22 жовтня 1902 р. М. Павлик закликав українську інтелігенцію допомогти селянам позбутися ейфорії від певних отриманих досягнень і налаштувати селянство до подальшої боротьби за свої економічні права. Цілком слушною була його заувага щодо необхідності докласти значних зусиль 3 виховання солідарності селянства усієї Галичини й Буковини. Найціннішим, на нашу думку, можна вважати його заклик до діючих тоді українських політичних партій залишити суперечки i “[...] пристати до спілки і погодитися на хлопських інтересах, закла- 
даючи найперше спільний страйковий комітет у Львові, а рівночасно такі самі спільні страйкові комітети по всіх повітах і по всіх селах" ${ }^{26}$. Незважаючи на значну підготовчу роботу, в 1903 селянський страйк був менш масштабним. Це зумовлювалося певними попереджувальними заходами як землевласників, так місцевої влади.

Попри спроби поліції чинити різноманітні перешкоди, українські літератори разом з іншими провідниками українського національного руху продовжували агітаційно-роз'яснювальну роботу серед селянства, насамперед, шляхом розповсюдження відповідних листівок авторства В. Будзиновського та М. Павлика. Зокрема, згідно з донесенням дирекції поліції у Львові, у 1905 р. у м. Калуші було конфісковано 800 примірників листівки “Браття хлопи”, у якій згадані письменники закликали: “[...] Руські хлопи станьте до борби о ліпшу платню і о визволене з під шляхетської неволі”. [...] Зривайтеся як один муж в цілім краї до загального хлопського страйку і страйкуйте доки не підвищать вам значно платню за роботу на панських ланах"27. Зважаючи на те, що великі землевласники, заручившись підтримкою владних структур, за кілька років отримали певний досвід запобігання страйкам, представники літературної інтелігенції дещо змінили тактику і зробили ставку на пропаганду легальних шляхів організації рільничих страйків, свідченням чого була листівка "Браття хлібороби"28 авторства В. Будзиновського. У ній автор закликав: “[...] Браття хлібороби! [...] Ми взиваємо вас до легальної боротьби. Австрійська конституція дає нам ще способи законної боротьби перед неволею i визиском. Тим способом $\epsilon$ загальний страйк"29

Окрім цього, українські партійні часописи “Діло", “Свобода”, “Громадський голос” (Львів), “Зоря”, "Руска Рада" (Коломия), “Буковина" (Чернівці) та ін. регулярно вміщували дописи В. Будзиновського, I. Франка, К. Трильовського щодо способів легальної організації страйку. Практичною, на наш погляд, була "Наука для страйкуючих", надрукована у газеті “Свобода”, де селянам у доступній формі роз'яснювалося, що “[...] Спокійний страйк є законом дозволений. Кожному вільно страйкувати, намовляти до страйку та організовувати страйк. [...]Але невільно іти на чужий грунт зганяти страйколомів, ані їх бити, ані їм грозити словами, і невільно примушувати кого -небудь до страйку силою або погрозою"з3. Також попереджували селян про те, що галицький намісник видав маніфест, у якому сказано, що “[...]за всякі гвалти, розгорнення чужосторонніх робітників будуть виновні остро карані",31.

Результат такої копіткої просвітньо-агітаційної діяльності не змусив себе чекати. “[...] Хлопскі страйки обхопили сих жнив 20 повітів, а в тих повітах кілька сот сіл ${ }^{32}$. Звичайно, що масштабів страйку 1902 р. не вдалося досягти, але це був добрий успіх, до якого значною мірою спричинилася і українська літературна інтелігенція.

Висновки. Незважаючи на загалом позитивні зміни, що відбулися в соціально-економічній сфері Галичини й Буковини після 1848 р., українське се- лянство повною мірою ними не користалося через те, що велике землеволодіння так і не було скасовано, а земельні магнати продовжували зберігати панівне становище та диктувати свої умови. В той же час внаслідок певних соціальних змін, український селянин поступово почав користуватися правами, наданими конституцією, і активніше відстоював свої економічні та політичні інтереси.

Проведення аграрних страйків 3 метою підвищення платні ініціювали літератори - активні діячі Русько-української радикальної партії I. Франко, M. Павлик, В. Будзиновський, С. Данилович та К. Трильовський.

Практичні поради селянам щодо проведення страйків подав В. Будзиновський у статтях та брошуpax “Страйки по громадах", "Про страйк і бойкот”, "Про страйки" тощо. Окремі письменники В.Стефаник, Лесь Мартович, А.Чайковський та ін. проводили роз'яснювальну роботу безпосередньо в сільських читальнях та на спеціально організованих народних вічах.

Результат просвітньо-агітаційної роботи перевершив усі сподівання. Під час жнив 1902 р. застрайкували українські селяни понад двадцяти повітів Галичини й Буковини, і при цьому добилися реального підвищення зарплатні на $20-30 \%$.

Як Варто було очікувати, аграрні страйки призвели до спроб покарати найактивніших організаторів та лідерів страйкуючих з метою залякати селянство від подібних виступів у майбутньому. Однак ці дії досить швидко були нейтралізовані літераторамиправниками а також депутатами австрійського парламенту та галицького і буковинського сеймів.

\section{Reference:}

${ }^{1 .}$ Botushanskyi V. Silske hospodarstvo Bukovyny (druha polovyna XX - pochatok XX st.) / V. Botushanskyi. - Chernivtsi: Zoloti lytavry, 2000. $-336 \mathrm{~s}$.

2. Vitenko M. Polsko-ukrainski vzaiemyny v Halychyni ta selianskyi straik 1902 r. / M. Vitenko // Halychyna, 2014. № $25-26$. - S. $194-200$.

${ }^{3}$ Pohrebenyk F. Les Martovych. Zhyttia i tvorchist / F. Pohrebenyk. - K.: Dnipro, 1971. - 196 s.; Pohrebennyk F. Vasyl Stefanyk. Seminarii / F. Pohrebenyk. - K.: Vyshcha shkola, 1979. $-283 \mathrm{~s}$.

4. Krasivskyi O. Ya. Halychyna u pershii polovyni KhKh st. Problemy polsko-ukrainskykh stosunkiv / O.Krasivskyi. Lviv, 2000. - $416 \mathrm{~s}$.

${ }^{5}$ Hud B. Ukrainsko-polski konflikty novitnoi doby: etnosotsialnyi aspekt / B.Hud. - Kharkiv: Akta, 2011. - $321 \mathrm{~s}$.

${ }^{6}$ Botushanskyi V. Silske hospodarstvo Bukovyny (druha polovyna KhIKh - pochatok KhIKh st.) / V. Botushanskyi.... - S. 105.

${ }^{7}$ Demkovych-Dobrianskyi M. Ukrainsko-polski stosunky u KhIKh storichchi / M.Demkovych-Dobrianskyi. - Miunkhen: Ukrainskyi vilnyi universytet, 1969. - S. 90.

${ }^{8 .}$ Botushanskyi V. Silske hospodarstvo Bukovyny (druha polovyna KhIKh - pochatok KhIKh st.) / V. Botushanskyi... - S. 105.

9. Stefanyk V. Palii / V.Stefanyk // Vasyl Stefanyk Tvory / upor. V.Lesyn ta F.Pohebennyk. - K.: Vydavnytstvo khudozhnoi literatury "Dnipro", 1964. - S. 131-143.

${ }^{10 .}$ Dilo (Lviv), 1886. - 3 kvitnia; 22 kvitnia; 1890. - 9 kvi- 
tnia.

11. Khliborob (Lviv), 1891. - Ch. 1. - S. 7.

12. Dilo (Lviv), 1897. - Ch. 207. - 13 (25) veresnia. - S. 2.

13. Tsentralnyi derzhavnyi istorychnyi arkhiv u Lvovi (dali TsDIAL Ukrainy), f. 663, op. 1, spr. 179, ark. 1.

14. Hromadskyi holos (Lviv), 1902. - Ch. 10. - S. 74.

15. Hromadskyi holos (Lviv), 1902. - Ch. 8-9. - S. 55.

16. TsDIAL Ukrainy, f. 663 , op. 1 , spr. 178 , ark. 9.

17. Zoria (Kolomyia), 1902. - Ch. 2. - S. $2-16$.

18. Zoria (Kolomyia), 1902. - Ch. 4. - S. 2 - S. 16.

${ }^{19}$ Hromadskyi holos (Lviv), 1902. - Ch. 13. - S. 98.

20. Budzynovskyi V. Straik i boikot... - S. 17.

${ }^{21}$ Halychanyn (Lviv), 1902. - Ch. 158. - S. 1.

22. Dilo (Lviv), 1902. - Ch. 225. - S. 2.

23. Levytskyi K. Istoriia politychnoi dumky halytskykh ukraintsiv / K.Levytskyi ... - S. 374.

24. Khlopska pravda (Kolomyia), 1903. - Ch.2. - S. 9.

${ }^{25 .}$ Pavlyk M. Shcho teper diiaty? Pysmo M.Pavlyka do zizdu Rusko-ukrainskoi radykalnoi partii z 22.10. 1902 r. i dodatok / M. Pavlyk. - Chernivtsi: Z drukarni "Ruskoi rady", 1902. - S. $16-17$.

26. Pavlyk M. Shcho teper diiaty? Pysmo M.Pavlyka do zizdu Rusko-ukrainskoi radykalnoi partii z 22.10. 1902 r. / M. Pavlyk... - S. 17

27. TsDIAL Ukrainy, f. 146, op. 8, spr. 591 ark. 1.

28. TsDIAL Ukrainy, f. 146, op. 8, spr. 592 ark. 1.

29. TsDIAL Ukrainy, f. 146, op. 8, spr. 592 ark. 1.

30. Svoboda (Lviv), 1906. - Ch.20. - S. 3.

31. Zoria (Kolomyia), 1903. - Ch. 5. - S. 24

32. Svoboda (Lviv), 1906. - Ch. 30. - S. 1.

Mykola Guivaniuk. Literary intellectuals' impact on farm laborers' strike movement in Galicia and Bukovyna in early twentieth century. The article highlights one of the most crucial events in the course of the national history in early $20^{\text {th }}$ century, namely, farm laborers' strike movement in Galicia and Bukovyna, for defending their traditional rights to economic thriving. The secular intellectuals' elite - men of letters and publicists - played an outstanding role in encouraging farm laborers to go on economical strike.

The focus of the research revolves around push-and-pull factors of agrarian strikes. Furthermore, literary intellectuals, having public education and propaganda in their hands, considerably influenced strike movement organization and succored their immediate assistance.

The author puts an emphasis on I. Franko, M. Pavlyk, V. Budzynovskyi, S. Danylovych, L. Martovych, A. Chaikovskyi, and K. Tryliovskyi's significant contribution to organizing resistors' movement.

The researcher enhances the best value of literary intellectuals in the course of educative and agitation activities and favorably reflects intelligentsia's role in urging farm laborers of 20 districts of Galicia and Bukovina to strike during the Harvest of 1902 and gain increase of wages.

Consequently, agrarian strikes resulted in farmers'intimidation and prevention them from being engaged in further mass unrest. Importantly, the laborers' turmoil was immediately counteracted by legal writers, deputies of the Austrian Parliament as well as Galician and Bukovina Diet.

Key words: propaganda/agitation, farm laborer strike, Galicia, Bukovyna, Ukrainian men of letters.
Гуйванюк Микола - кандидат історичних наук, доиент кафедри Історії Украйни Чернівецького національного університету імені Юрія Федьковича. Коло наукових інтересів: історія Галичини й Буковини другої половини ХIX - початку XX ст., український парамілітарний рух початку XX ст. Громадсько-політична діяльність украӥнських письменників Галичини й Буковини (кінець XIX - початок ХХ ст.) Автор 110 наукових праць, в т. ч. 2-х моногpaqiŭ.

Mykola Guivaniuk - PHD in History, Associate Professor, the Dept. of History of Ukraine Yuriy Fedkovych Chernivtsi National University. Research Interests: history of Galicia and Bukovina of the second half of XIX - first part of XX centuries. Ukrainian paramilitary movement of the early twentieth century. Socio-political activity of Ukrainian writers Galicia and Bukovina (late XIX - early XX century.) The author of 110 scientific publications including 2 monographs.

Received: 11-10-2016

Advance Acces Publischer: November 2016

(C) M. Guivaniuk, 2016 